\title{
Os Maestros do Verbo: a constituição da legalidade interna da música popular urbana brasileira
}

\section{Resumo}

Neste artigo, busco fornecer subsídios à compreensão do processo que desencadeou a mudança da posição social do gênero musical samba na década de 1930. Procuro mostrar que um âmbito auto-referido de discussão sobre o samba emergiu no bojo do desenvolvimento da comercialização do "produto" música popular, o que pavimentou a emergência de um plano de debates cujos participantes eram verdadeiros especialistas em dissertar sobre a nova forma de arte. De outro lado, essas figuras ora rivalizavam, ora cooperavam com os intelectuais "não especializados" que se arriscavam a tecer comentários sobre a manifestação em pauta, de modo a formar um interstício dialógico que fomentou o assentamento de diversas "verdades" sobre a música popular urbana. Dos contatos, embates e cooperações traçados entre esses dois níveis de produtores de discursos, conjunturas históricas teriam sido forjadas, reestruturadas e reinterpretadas, fato que ensejaria novos modos de visão e o irrompimento e a cristalização de instituições e obras.

Palavras-chave: Música Popular Brasileira. Samba. Choro. Intelectuais.

\footnotetext{
"Professor Adjunto I do Departamento de Ciências Sociais do Instituto de Ciências Humanas da Universidade Federal de Juiz de Fora. (Brasil). E-mail: vivaraiz@gmail.com
} 


\section{The maestros of the word: the establishment of the internal legality in the Brazilian Urban Popular Music.}

\section{Abstract}

In this article I seek to provide a basis for understanding the process that triggered the change of the social position of samba in the 1930s. I try to show that a self-referred framework of discussion about samba emerged at the heart of the development of the commercialization of the "product" popular music, which paved the way to the emergence of a set of debates whose participants were experts in discoursing about that new form of art. On the other hand, these agents both rivaled against and cooperated with other intellectuals who ventured to produce commentaries about the musical genre in question. These two categories of intellectuals shaped a dialogical interstice that promoted the establishment of several "truths" about the urban popular music. From the contacts, the conflicts and the cooperation drawn between them, historical junctures would be forged, restructured and reinterpreted, a fact that would enable new ways of vision, the eruption and crystallization of institutions and songs.

Keywords: Brazilian Popular Music. Samba. Choro. Intellectuals.

\section{I - A força da criação ou a criação da força?}

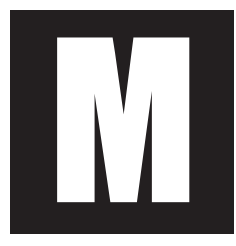

uito vem sendo escrito sobre relevante fenômeno sucedido no universo da música popular brasileira, o do processo sócio-histórico que deu margem à nacionalização do samba'. Grosso modo, saltou à vista dos estudiosos voltados ao tema a elevação de manifestações artísti-

\footnotetext{
${ }_{1}^{1}$ Apenas para citar os que abarcam centralmente a problemática assinalada, reporto-me a Bissoli (2004), Braga (2002), Caldeira (1982), Cunha (2004), Fenerick (2002), Frota (2003), Mccann (2004), Napolitano (2007), Pedro (1980), Rivron (2010), Shaw (1999), Stroud (2008), Tinhorão (2004), Vasconcellos e Suzuki (1985), Vianna (2004) e Wisnik e Squeff (1983). Para uma análise da bibliografia específica sobre música popular brasileira, ver Napolitano (2002) e Naves et al. (2001).
} 
cas específicas - algumas menoscabadas ou perseguidas - ao estatuto de identificadoras do país em determinado contexto. Embora lançando mão de abordagens díspares, houve grande contribuição desses trabalhos à compreensão das intricadas transformações sociais, políticas, econômicas, tecnológicas e intelectuais que engendraram a ascensão e o decorrente vínculo do elemento nacional-popular nas artes com os interesses e projetos do primeiro governo Getúlio Vargas (1930-1945). Entre os abundantes eventos que teriam exercido efeito sobre o processo aventado, podem ser destacados, no rol de referências constantes, segundo brevíssimo e despretensioso balanço das obras dos autores mencionados, ao menos quatro: 1) a atuação consciente e ativa do aparelho estatal em busca de símbolos que pudessem expressar o ideal de uma nação unificada ao longo da década de 1930; 2) a racionalização capitalista conjugada com interesses do novo governo que catalisou as atividades da indústria do disco e as estações de rádio; 3) os contatos de diversos feitios travados entre intelectuais, artistas influentes e os produtores daquelas manifestações musicais populares; 4) as forças de penetração e de resistência de que supostamente era dotado o gênero musical oriundo das "camadas desprivilegiadas".

A descoberta desses marcos representou notável avanço no tocante ao conhecimento das relações que envolviam o samba, a constituição do comércio musical popular e a construção da nacionalidade, o que conferiu à discussão uma densidade acadêmica dificilmente conquistada por outros gêneros musicais (Napolitano, 2002). Por outro lado, cabe ressaltar que, a despeito do êxito que tais trabalhos apresentem, a maioria não logrou ultrapassar o apontamento de conexões que reduziam a arte popular urbana nascente a ordens diversas, fossem estas políticas, comerciais, governamentais etc. Quero dizer, com isto, que não houve uma ênfase analítica por parte dos acadêmicos citados com respeito às injunções simbólicas e materiais específicas ao domínio do samba. Sempre subsumindo a arte popular à esfera dos assuntos mais reluzentes e socialmente 
importantes que lhe circundavam, os estudiosos não se deram conta de que o vislumbrado "o" samba, de início, já assomava no formato de "os" sambas. Tal desatenção epistemológica prejudicou a visualização mais aprimorada do equilíbrio de tensões que irrompia e fazia irromper um domínio artístico popular relativamente autônomo - talvez o primeiro do Brasil. Falo de um circuito dotado de instituições próprias de reprodução comercial e de um público cultor, de um batalhão de artistas identificados enquanto pertencentes ao gênero - isto é, de autoproclamados "sambistas" - e, por fim, de "legisladores" que se atinham quase que de modo exclusivo à ordenação simbólica do novo universo - consistindo este último, em minha opinião, no item menos pesquisado pela bibliografia.

Ressalte-se a aparição desses personagens semiobscuros na história da música popular urbana, aparição que ensejou a atividade de delimitação e a decorrente autorreferência discursiva que, a partir de certo instante, passava a impregnar todas as instâncias que discorriam sobre a mais nova manifestação digna de nota. $\mathrm{O}$ estabelecimento de polarizações entre um "mau" e um "bom" samba, ofício desempenhado com mestria pelas figuras em pauta, traduzia, em termos ideais, a crescente luta pela legitimidade interna no mundo das artes populares, face reversa do aumento de relevância social, política e comercial logrado pelo gênero, alçado à condição de "a" arte popular de então. As dissensões vindas a lume, ademais, podiam ser percebidas em meio a diversos suportes, tais como letras de canções, livros exaltadores, palestras eruditas, matérias jornalísticas etc. Diziam respeito, sobretudo, à preocupação demarcatória tanto em relação à forma "correta" de sua reprodução, quanto sobre a natureza territorial das "origens" dessa arte popular que vinha de se firmar. "Morro", "cidade", o Rio de Janeiro como um todo ou ainda o "coração" - dentro de um distanciamento poético mais piegas -: estava aberta a contenda pela paternidade, origem e "correta" manutenção do samba em uma figuração de intensas transformações sociais e de solidificação de 
novas instituições. E aqui penetro um terreno de pesquisas praticamente inatingido pela bibliografia disponível, mormente quando se trata da análise das cisões postas em jogo no embate pela imposição da "verdadeira" ou "falsa" representação simbólica das manifestações musicais populares urbanas e de seus artífices.

Seguindo as pistas de sociólogos contemporâneos atentos aos processos de construção do mundo social por meio de atos discursivos, comentários, exegeses etc., caso de Pierre Bourdieu (2004, p. 96), para quem [...] será necessário tornar-se cego para não enxergar que o discurso sobre a obra não é um simples acompanhamento, destinado a favorecer sua apreensão e apreciação, mas um momento da produção da obra, de seu sentido e de seu valor, cientificamo-nos de que o discurso sobre as obras, os gêneros artísticos e todo e qualquer ato referido à sedimentação de divisões, classificações e fronteiras simbólicas relativas ao universo da arte - seja esta qual for - não restam inócuos. Percebe-se, assim, que muito do valor das obras deriva eventualmente do poder reunido pela voz de quem é autorizado a dizer o quê e como, ou quem se faz passível de detração, louvação ou indiferença no reino da criação. E é justamente a esta tarefa, a de desvendar os caminhos de legitimação percorridos pelo samba em seus meandros intelectuais, que me proponho neste artigo.

Apoiado nas descobertas dos acadêmicos mencionados acima busco fornecer maiores subsídios aos processos esquadrinhados por meio de um refinamento analítico que ponha em primeiro plano o escrutínio da elaboração intelectual daqueles que se ocuparam com o estatuto do samba, sobretudo na década de 1930, instante em que a transformação da posição social do gênero se completou. Procuro mostrar que um âmbito autorreferido de discussão sobre o samba emergiu no bojo do desenvolvimento da comercialização do "produto" música popular, o que pavimentou a existência de um plano de debates cujos participantes eram verdadeiros "entendidos", especialistas em dissertar sobre aquela nova 
forma de arte. Essas figuras ora rivalizavam, ora cooperavam com demais intelectuais que se arriscavam a tecer comentários sobre a manifestação em pauta, de modo a formar um interstício dialógico em que o resultado foi o do assentamento de diversas "verdades" sobre a música popular urbana. A interpenetração entre as investidas desses dois tipos de intelectuais teria ensejado, além de outras coisas, a Vargas e seu aparato de Estado tomarem ciência das reais potencialidades daquele prêt-à-porter artístico que, inusitadamente, Ihes caía ao colo. E só assim o "bom" samba, categoria reafirmada em meio aos construtos eruditos e nativos, tornou-se apto a assumir o posto de identificador da nação.

\section{II - A vaga do samba}

As três primeiras décadas do século XX, no Brasil, presenciaram a ascensão de uma cultura popular lato sensu no universo musical do Rio de Janeiro, cultura esta escorada nos marcantes avanços tecnológicos que alcançavam o país àquela altura (Braga, 2002). Tendo como principais veículos institucionais o rádio, o disco, o já conhecido teatro de revista e, do lado de sua justificação e promoção discursiva, uma parcela da imprensa que passava a acolher sistemática e continuamente temas antes relegados a um tratamento secundário e esporádico - jornais diários, periódicos matutinos e vespertinos, revistas em geral e especializadas etc. ${ }^{2}$ - a música popular passava a ofertar a possibilidade de profissionalização, ainda que bem poucos obtivessem o êxito e a relativa independência econômica, em tese, disponíveis. No que concerne especificamente ao rádio, em 1930 contabilizavam-se quatro estações na cidade do Rio de

\footnotetext{
${ }^{2}$ Marialva Barbosa (2007, p 48) pontua as modificações que imperavam entre os jornais cariocas nas três primeiras décadas do século XX. Alguns surgidos nesse meio-tempo abandonaram o antigo padrão à francesa, isto é, o de trazer longas digressões políticas e opinativas e argumentações bem fundamentadas em prol de uma "leveza" à americana. Rápidas manchetes e textos concisos e sensacionalistas, ilustrações diversas, temas voltados ao cotidiano citadino,
} 
Janeiro. Um crescimento vertiginoso pôde ser entrevisto em curto espaço de tempo, pois em 1935 mais dez emissoras se somavam àquelas. Este número de estações aumentou até a década de 1950, atingindo cerca de vinte na cidade do Rio de Janeiro e 300 espalhadas país afora. O rádio ocupava o posto de principal veículo de comunicação, dado que $85 \%$ dos lares brasileiros contavam pelo menos com um aparelho receptor, segundo pesquisa realizada no ano de 1945 (McCann, 2004, p. 24). Infiltravase no cotidiano do grosso da população com seus programas de notícias, humorísticos e o veio principal a partir de meados de 1932, a música popular. Neste ano, um decreto presidencial de Vargas, o 21.111/1932, permitiu a venda de quotas do tempo de transmissão das rádios a anúncios comerciais de particulares, modificando o caráter e a estrutura dos programas produzidos até então (McCann, 2004, p. 23).

Com o fito de expandir os sinais radiofônicos nativos a todo o território nacional, o decreto de Vargas deu margem à formação de estações de rádio relativamente libertas de amarras e injunções regulamentadoras. Passava-se, por conseguinte, a investir no arrebatamento de uma quantidade maior de público ouvinte por meio de expedientes diversos. Quadros mais "ligeiros" e de feições popularescas tornavam-se praxe naquele ínterim, em oposição ao que se via anteriormente. As emissoras faziam uso extensivo de uma nova sorte de programação, a qual reinava quase que absoluta, caso do pioneiro Programa do Casé, protótipo do profissionalismo que tomou conta do espaço radiofônico (Casé, 1995; Cabral, 1996a). Baseado em ineditismos pontuais como o preenchimento sonoro por meio de backgrounds executados durante os intervalos das apresentações e a criação de jingles para os produtos anunciados, o programa alcançou um sucesso tremendo. Artistas do naipe de Noel Rosa, Marília Batista, Carmen Miranda, Francisco

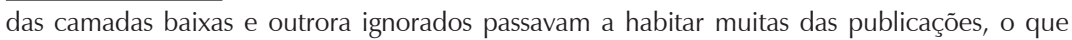
incrementou a concorrência entre os veículos. Revistas de variedades presentes desde algum tempo também abrigavam notícias voltadas às manifestações musicais populares, casos de $O$ Careta, Revista da Semana, Fon-Fon, Para Todos, Cena Muda, O Malho etc. 
Alves, Orlando Silva, Almirante, Orestes Barbosa e mais uma constelação de artistas vinculados ao samba e ao choro encontravam, pela primeira vez, um local exclusivo para dar vazão às canções que criavam e/ou interpretavam. Em 1935, três anos após o estabelecimento do programa, das catorze estações existentes no Rio de Janeiro, nada menos do que doze delas escoIhiam como carros-chefe programas baseados em música popular, ou, mais especificamente, em samba. Prova do estrondoso sucesso alcançado pelo formato inaugurado por Ademar Casé.

A contrapartida do início desta "fase áurea" da música popular urbana no rádio, conforme alcunhada mais tarde pelo crítico e jornalista Ary Vasconcelos, era dada pela indústria fonográfica, presente em território nacional há quase trinta anos. A primeira indústria fonográfica, a Casa Edison, gravava majoritariamente desde seu assentamento no Brasil, em 1902, canções nativas de teor popular (Franceschi, 2002). As gravadoras logo encontraram nas emissoras de rádio um eficaz meio de divulgação de seus produtos e de decorrente engorda de seus lucros. Em compensação, as estações preencheram suas grades com formatos musicais de fácil assimilação, velhos conhecidos do grande público. Ressalte-se que a comercialização de gravações contendo formas musicais dessa espécie antecedia em praticamente trinta anos o advento das estações comerciais. Quando da liberação da veiculação de reclames nas rádios, o Brasil contava com quatro grandes indústrias fonográficas disputando um mercado ascendente. ${ }^{3} \mathrm{O}$ estado de penúria no manejo da cultura legítima apresentado pela maioria da população auxiliava a perpetuação do "gosto" por

\footnotetext{
${ }^{3} \mathrm{O}$ advento da gravação elétrica, em 1927, processo mais simplificado e com um grande ganho de qualidade no som, trouxe concorrentes de peso à pioneira Odeon no Brasil. Aportavam por aqui a RCA Victor, a Columbia e a Brunswick, que logo encerrou suas atividades. Note-se que se trata de empresas multinacionais rendidas neste instante à gravação e à divulgação majoritárias de produtos nacionais. Preferiram, de modo inusitado, estabelecer um mercado próprio musical desde seu início em vez de importarem chapas gravadas de seus países de origem, conforme costumavam agir alhures (McCann, 2004, p. 26).
} 
essas produções que, em princípio, miravam o maior contingente possível de consumidores. Após a entrada em cena do rádio e o barateamento dos aparelhos de reprodução sonora esse número só tendeu a aumentar ${ }^{4}$.

Outro fator se somou ao circuito mercantil da década de 1930. O secular carnaval, a partir dos anos 1920, entronizou o samba, junto com a marcha, no rol de principais estilos musicais que animavam esta disputada e esperada festa anual. Compositores e cantores pleiteavam ansiosamente o sucesso do carnaval em meio às gravações de discos, em um primeiro momento, e, já na década de 1930, visando também à celebridade nas estações de rádio. Isto significa dizer que um parâmetro específico de produção e de concorrência de obras musicais se estabelecia, obrigando as gravadoras a procurarem novas criações e criadores incessantemente. O mesmo e sintomático ano de 1932 abrigou o início dos concursos carnavalescos, agora no exitoso arranjo das chamadas escolas de samba que, dentro de um curto espaço de tempo, venciam a disputa com as "imemoriais" grandes sociedades, ranchos carnavalescos e demais organizações (Cabral, 1996b, p. 19-94). A nova imprensa com ares de profissionalismo que se firmava na década de 1920, sedenta por novidades quaisquer que fossem, verificava na possibilidade da promoção e organização de um desfile carnavalesco envolvendo esses grupamentos, que reuniam compositores relativamente afamados no universo dos discos, como Cartola, Ismael Silva, Brancura, Nilton Bastos, Paulo da Portela etc., bela oportunidade de alavancar o nome da empresa. Ademais, a imprensa escrita já organizava os desfiles dos ranchos carnavalescos desde a década de 1920, detendo certa intimidade com a tarefa que abraçava.

\footnotetext{
${ }^{4}$ Por exemplo, em 1929, mesmo antes do advento do rádio comercial, Francisco Alves, o cantor de maior sucesso no período, vendeu cerca de 120 mil discos de um único lançamento, enquanto em 1913 a venda de seis mil discos era algo considerado estrondoso (Franceschi, 2002, p. 224-225).
} 
O jornal Mundo Sportivo ([192-] apud McCann, 2004, p. 59), primeiro a propor e a agasalhar esta empreitada anunciava que [...] a sonora alma do morro descerá à cidade [...], promovendo o festival de "exotismo" - esta era uma das chaves de aceitação do samba pelas camadas superiores - a ser patrocinado neste ano em um desfile na Praça Onze, centro do Rio de Janeiro e "berço" simbólico e informal do samba. O golpe de mestre executado pelo meio de comunicação chamou deveras a atenção das estações de rádio, dos jornais concorrentes e das gravadoras de discos, complementando, destarte, a engrenagem que se armava em torno dos estilos musicais populares urbanos. Quer dizer, o processo de legitimação do samba junto - caracterizado por um público amplo, uma estrutura comercial e a decorrente conquista da dignidade de ser considerado um objeto conveniente à pauta jornalística -, veio, ao longo do período vislumbrado, encorpando-se e atinge o seu corolário, coincidentemente ou não -, com a chegada ao poder de Vargas.

\section{III - Tem bamba no samba}

Possuindo como carro-chefe o gênero musical que se convencionou chamar de samba 5 , a música popular urbana encontrou, dentro de curto espaço de tempo, uma audiência fiel e numerosa. Contudo, mesmo em uma década de intensa celebração comercial e de aparição em todas as mídias disponíveis, fazia-se possível a visualização de rastros de uma desclassificação a priori rebaixando os seguidores e amantes do elemento musical popular (Napolitano, 2007, p. 42). Espécie de reação destilada por aqueles que abominavam a emergência contumaz de um símbolo supostamente

\footnotetext{
${ }^{5}$ Para maiores informações sobre as nomenclaturas designativas de gêneros musicais existentes nesse período e as distinções musicológicas entre "os" sambas, consultar Sandroni (2001).
} 
atado às camadas inferiores, a identificação do samba como representantemor do mau-gosto e de inadequações várias efetuada na década de 1930 valia-se de argumentação que movimentava um racismo inveterado, um achincalhamento da "falta de costumes", da selvageria, da incivilidade etc., elementos ativos desde há muito no julgamento sobre as artes populares no Brasil. A diferença com respeito às críticas de um período pretérito, no entanto, eram muitas: por mais que os incomodados externassem sem mais suas opiniões, eles demonstravam tacitamente a aceitação da existência do samba. Ou seja, em maioria, os detratores do gênero da década de 1930 almejavam corrigir, civilizar e higienizar uma espécie de samba que consideravam desvirtuada, aquela que teria mantido os traços julgados "detestáveis", intrínsecos às camadas mais baixas. Frise-se, porém, que não se encontrava mais a postulação de políticas que dessem conta por completo do extermínio do gênero musical popular, algo corrente até mesmo entre senadores da República na década de 1910 (Sandroni, 2001, p. 89). O samba, neste ponto, já teria garantido seu direito à existência.

O articulista e burocrata componente do governo de Getúlio Vargas, Almeida Azevedo (1935 apud Napolitano, 2007, p. 42), em 1935, por exemplo, escrevia na Revista Voz do Rádio que

O horrível samba de morro, a força de ser maltratado, seviciado, anda por aí desamparado, sem juiz de menores que olhe por ele, sem polícia de costumes que o proteja, sujo, malcheiroso etc. O samba, que é carioca, ficaria bem integrado na família da música brasileira se não fosse o irmão vagabundo, desobediente, que anda em más companhias, cheio de maus costumes e que não quer limpar-se nem a cacete [...]. O rádio pode, se o quiser, higienizar o que anda por aí com rótulo de coisas nossas a desmoralizar nossa cultura e bom gosto.

Em 1939 o historiador Pedro Calmon e o escritor José Lins do Rêgo enroscaram-se em contenda reveladora do estado das artes da aceitabilidade do gênero samba e de alguns de seus personagens célebres e 
celebrados para o desempenho do papel de "símbolos nacionais". Calmon defendia que o exotismo exacerbado exibido pela cantora Carmen Miranda em sua longa estada nos EUA, na década de 1930, prejudicava a imagem de um país que desejava entrar no rol dos "cultos e civilizados". José Lins do Rêgo (apud McCann, 2004, p. 63-64), de sua parte, o acusou de preconceituoso e completo desentendido no assunto, motivo pelo qual o intelectual deveria se calar em vez de proferir asneiras contra [...] os ritmos de nossa terra e a riqueza de nosso substrato psicológico. Em 1941, foi o articulista e radialista Renato Alencar quem deu a receita na revista Scena Muda para novamente não passarmos vergonha na frente dos ianques. Desta feita, o cartunista Walt Disney visitaria a escola de samba Portela a fim de tomar ciência dos ritmos "bem nossos". Segundo Alencar (apud Napolitano, 2007, p. 42),

O samba é um dos ramos das danças importadas com o tráfico negreiro e que se fixou e evolucionou entre nós. [...]Divide-se em duas classes: o samba de morro, a batucada, dança litúrgica bárbara e sensual [...] [que] não tem beleza nenhuma, é monótono e triste como todo produto de povos torturados e incultos; o outro é o samba de arte, suportado no salão e nutrido pela influência dos mais altos pendores líricos.[...] [Na Portela estavam] Negros a cantar e dançar na monotonia de orações lúgubres, num terreiro de subúrbio cercado de casebres, onde uma população subalimentada, maltrapilha, parece fazer coro com os sons dos atabaques melancólicos [...].

Não obstante, como no caso do historiador Calmon e de José Lins do Rêgo, tais declarações não encontravam mais como resposta um silêncio abrasador, que poderia significar certa condescendência, à maneira do que ocorria em passado nem tão longínquo. As asserções eventualmente recebiam réplicas exaltadas e bem fundamentadas em diversos meios de comunicação. Muitas vezes futuros medalhões da cultura e política nacionais, casos da poetisa Cecília Meirelles, em 1941, e do jovem polí- 
tico então comunista Carlos Lacerda, em 1936, se ocupavam do assunto, revelando que uma altercação entre vozes audíveis e penas legíveis assomava naquele instante. Lacerda (apud Napolitano, 2007, p. 35).deixava claro na Tribuna Popular que visava ao aproveitamento do samba na luta de classes, invertendo a visão dos preconceituosos colunistas antevistos:

O samba nasce do povo e deve ficar com ele. O samba elegante das festanças oficiais é deformado: sofre as deformações na passagem de música dos pobres para divertimento dos ricos. O samba tem que ser admirado onde ele nasce, e não depois de roubado aos seus criadores, transformado em salada musical para dar lucro aos industriais da música popular [...]. O samba é música de classe. O lirismo da raça negra vive nele [...] é preciso defender o samba contra as concepções de seus deformadores, que preferem mostrá-lo como curiosidade exótica [...]. Quando os oprimidos vencerem os opressores o samba terá o lugar que merece.

Já Cecília Meirelles (apud Braga, 2002, p. 399-400)., no jornal A Manhã, enfatizava o papel educativo e mesmo integrador que o samba poderia exercer junto a camadas humildes, valorização da alteridade cultural avant la lettre contida em forma artística a meio-caminho da glorificação nacional:

Quem se der ao trabalho de subir a um desses morros pobres onde tem escolas de samba e levar olhos ansiosos de compreender e interpretar verá que o samba pode não ser tão formidável como se diz, às vezes, mas está cumprindo uma missão que não deixa de ser educativa e que enternece aos que gostam da humanidade e que desejariam vê-la melhorada por meios pacíficos. [...] a escola de samba, além de cumprir uma função integradora através do jogo e do lúdico, é uma lição de convívio, cordialidade e boas maneiras entre os cidadãos, além da valorização espontânea da tradição, tão perseguida pelas elites cultas naquele momento. Por tudo isso, o samba concorria para a educação, mesmo sem precisar ser "melhorado". 
A despeito de possíveis idiossincrasias e das situações diversas a que se referiam, alguns traços gerais que os excertos transcritos continham podem ser de grande valia à melhor compreensão dos propósitos deste artigo. O fato de terem sido escritos por personagens não pertencentes de modo imediato ao universo do samba, por exemplo, diz muito sobre o teor das discussões levadas a cabo. Ainda que suas posições sociais de articulistas secundários e intelectuais em ascendência conferissem determinado peso às conclusões que defendiam, percebe-se que nenhum esbanjava traquejo no tratamento de questões internas ao gênero musical. Os detratores do samba discorriam ora sobre o caráter africano, lúgubre, maltrapilho, ora sobre a pobreza e a miséria de seus cultores, locais etc. Por outro lado, os defensores do samba listados estavam mais interessados em vincular o samba fosse à luta de classes, à educação, fosse à sua glória internacional e intelectual do que em perscrutar sua propriedade musical, seus locais de reprodução, em valorar seus personagens por meio de trunfos artísticos que reunissem etc. Ora, por mais nítida se manifestasse a divisão que apartava determinado samba "bom" do "ruim" em meio aos argumentos antepostos, a cisão embasava-se em parâmetros heterônomos à reprodução da atividade propriamente artística, caso dos referidos pertencimento de classe e da exploração capitalista em Lacerda, da necessária "higienização" em Alencar e Azevedo, da vergonha ou do orguIho que o gênero suscitava perante um público internacional em Calmon e Rêgo, do racismo atuante em Alencar e Azevedo, do rol educacional em Meirelles etc. Quer dizer, se de um lado, disputas como as retratadas passaram a ser reiteradas e os ataques ao samba - à imagem e semelhança dos proferidos no século XIX à totalidade do elemento musical popular deparavam-se com contestações, o teor das respostas não ultrapassava a inespecificidade de um diálogo alheio ao domínio musical. 
Tratando-se, todavia, de desclassificações ou de defesas mais desclassificadas ou não, o fato é que vinculações entre arte e sociedade da natureza das examinadas atravessaram décadas a fio. Se, por um lado, é certo que tais classificações encontravam-se e permanecem, ainda em nossos dias, em franco funcionamento - pois frutos de incessantes disputas envolvendo frações de interessados e representantes de diversas instituições situadas em posições desiguais à cata de legitimidade -, por outro, cada figuração perscrutada apresenta termos e significados específicos, dando liga às oposições fundantes da atividade em jogo. Por meio do intercâmbio entre uma análise ora sincrônica, ora diacrônica, o sociólogo capacita-se à captação de eventuais modificações de sentido que, ao longo da história, possam emergir de disputas envolvendo uma mesma forma artística. No caso em exame, é notório que a legitimidade irrestrita conferida à legislação musical vigente no século XIX e início do XX por críticos eruditos deslocou-se imperceptivelmente (Fernandes, 2010). O glamour discursivo, reservado àqueles que, no passado, se deleitavam com as obras "majestosas", irrompia em uma oposição paralela. Seria algo um tanto quanto insólito, por exemplo, que articulistas da década de 1940 comparassem frente a frente o gênero musical popular, qual fosse, com produções eruditas - forma corrente de apreciação e depreciação no século XIX. Quer dizer, mesmo quando tratado a partir de pontos de vista relativamente externos, o universo referencial que passava a nutrir as discussões sobre o elemento popular circunscrevia-se sobre si. Esta nova maneira de percepção, por sua vez, é devedora do surgimento de novos personagens, de acordo com o que será visto na seção seguinte.

\section{IV - Na roda do samba}

Desde princípios do século XX, reuniões animadas pelos estilos musicais chancelados sob as nomenclaturas genéricas samba e choro atraíam 
jornalistas de segundo escalão, cronistas menores e demais figurantes da incipiente vida cultural da então capital federal. Personagens recrutadas aos borbotões pelo próspero espaço do periodismo no pós-proclamação da República, esses escribas que nada tinham a perder abraçavam sem peias as atividades jornalísticas pouco apreciadas pelos seus pares, no caso, reportagens policiais, de festividades e sobre pretendentes às artes menores que ascendiam (Napolitano; Wasserman, 2000; Moraes, 2006; Fernandes, 2011; Coutinho, 2006). Ao mesmo tempo em que davam a conhecer a seus leitores as engrenagens de um cenáculo até então restrito aos nativos, esses intelectuais improvisados, provenientes sociais das mesmas fileiras populares a respeito das quais dissertavam, discorriam com a desenvoltura de insiders acerca de obras, dos criadores e de logradouros que abrigavam as manifestações em pauta. Os julgamentos embutidos em suas crônicas e reportagens terminaram traçando os contornos do gosto que viria a reger tanto os padrões de composição dessas canções quanto seu consumo. Rotinizaram ainda o uso da expressão "artista", até então reservada à "sublimidade", no léxico empregado para a descrição de seus agraciados. Nascia, pois, um circuito artístico distinto dos tradicionais erudito ou folclore rural -, onde se tornava possível a um Pixinguinha ou a um Sinhô, por exemplo, ser guindado à categoria de maioral em razão de parâmetros de avaliação voltados aos feitos executados no domínio ao qual pertenciam - situação impensável no Império, quando formas musicais parelhas eram defenestradas sem mais pelas "opiniões sérias", não atraindo análise que as apreendesse em suas particularidades.

Decerto, antes mesmo que as manifestações populares urbanas desaguassem nas ondas do rádio, um nomos emergia em meio a páginas de jornal e revistas variadas. Avançando aos anos 1930, momento em que a atividade radiofônica e a indústria fonográfica catalisaram de vez a produção artística, o métier legislativo principiava a efetuar a separação entre os 
artistas considerados "comerciais", "vendidos" ou "impuros" dos "autênti$\cos ^{\prime \prime}$, "puros" e "desinteressados", sinalizando a nova lógica que recobria a música citadina. As prescrições elaboradas pelos cronistas-foliões forjaram uma divisa até então inexistente, evento que outorgou certa autonomia aos parâmetros de julgamento fundantes do novo domínio. Note-se que a relatada ascensão dos meios comerciais de reprodução artística acompanhou-se da filtragem simbólica embasada nos critérios desenvolvidos pelos personagens em relevo, o que fez dessas manifestações musicais populares as primeiras no Brasil dotadas de um grupo de intelectuais específicos, inauguradores da arte de demarcar seu passado, presente e futuro.

A maturidade do trabalho operado por essa crítica especializada confirmou-se através da safra de quatro livros lançada pelos cronistasjornalistas Jota Efegê (João Ferreira Gomes, 1902-1987), Vagalume (Francisco Guimarães, 187?-1946), Orestes Barbosa (1893-1966), e o carteiro Animal (Alexandre Gonçalves Pinto, 187?-194?) entre os anos de 1931 e 1936, todos voltados à reportagem da boêmia musical. As normatizações contidas nas obras O Cabrocha (Efegê, 1931), Na Roda do Samba (Guimarães, 1978), Samba: sua história, seus poetas, seus músicos, seus cantores (Barbosa, 1978) e O Choro: Reminiscências dos Chorões Antigos (Pinto, 1978) demonstravam-se pertinentes, o que não significa que elas não encerrassem discordâncias irreconciliáveis ${ }^{6}$. Vagalume, por exemplo, reputado como decano dos cronistas carnavalescos, firmou a elaboração de que o valoroso samba era o desinteressado, à margem do intuito do lucro, do comercialismo e da ganância que caracterizavam a rádio e o disco, denunciados por corromperem um ambiente outrora "puro":

O que hoje há por aí, tem apenas o rótulo, é um arremedo de samba (Guimarães, 1978, p. 29).

\footnotetext{
${ }^{6}$ Para uma análise detalhada das trajetórias, atividades e obras desses personagens, ver FERNANDES (2010, 44-77 e 120-129).
} 
Onde morre o samba? [...] Quando ele passa a ser artigo industrial - para satisfazer a ganância dos editores e dos autores de produções dos outros (Guimarães, 1978, p. 31). Hoje, o que inspira os sambistas e "sambestros" é a ambição do ouro... [...]. As músicas de hoje, são muito semelhantes umas com as outras, diferindo apenas no andamento, na mudança de compasso. Estamos no Império do Plágio. O samba industrializado, despertou a cobiça e fez surgir uma nova geração de autores... de produções dos outros (Guimarães, 1978, p. 89-90).

Eis a provável inscrição pioneira da eterna busca pelo éden perdido na música popular urbana. Ao passo que, um Orestes Barbosa, aliado dos artistas da rádio, não se vexava em louvar estes mesmos veículos por propagarem a manifestação musical que, em sua opinião, mais bem representava o Brasil: o samba - abrindo caminho à nacionalização midiática dos gêneros samba e choro:

O samba tem no rádio um grande servidor. O rádio é, no momento, um problema descurado por parte do poder. A cidade, que tanto the deve, precisa igualmente voltar para ele as suas vistas, prestigiando, colaborando para que ele cumpra as suas finalidades em prol do progresso geral (Barbosa, 1978, p. 111).

Não obstante, importa ressaltar, para além das discordâncias várias, que os autores citados lograram estabelecer um consenso que forneceu subsídio não só ao devir da crítica da música popular brasileira, como ainda aos próprios compositores e demais envolvidos na produção artística. O repertório que engloba as práticas musicais e demais caminhos possíveis de criação, a eleição das paragens carregadas de valor sentimental que representam os "berços" do samba e do choro - o "morro", a "cidade", as residências das "tias" baianas etc. -, o panteão dos dois gêneros musicais, as interdições e validações de uso de instrumentos musicais, modos de impostação de voz etc., e um ar saudosista, que impulsionava 
a busca de referências estéticas, grupais e ritualísticas no passado, receberam o primeiro sopro das penas desses engajados demarcadores.

Opiniões sistematizadas há décadas em jornais da capital, as asserções dos cronistas-legisladores ecoavam até mesmo nos ouvidos de artistas-intelectuais do calibre de Mário de Andrade e Villa-Lobos. O célebre impulso de Mário de Andrade em ir atrás de Pixinguinha para buscar informações, quando compunha o seu Macunaíma - e não de outro afamado qualquer filiado às novas manifestações -, no intento de ouvir o relato do que ocorria na casa da Tia Ciata - e não em outra casa de "tias" baianas das quais o Rio de Janeiro se fartava naquele instante -, torna-se compreensível a partir do instante em que se esclareça que tanto o sambista-chorão quanto o local sacralizado já haviam sido alvos de inúmeras reportagens laudatórias (Barboza; Oliveira Filho, 1979; Moura, 1995). Tratava-se, portanto, de um informante celebrizado pelos críticosjornalistas há mais de uma década, isto é, de figura esquadrinhada. O mesmo acontecia com a seleção dos homenageados por Villa-Lobos na composição Choros: os chorões Anacleto de Medeiros, Ernesto Nazareth e Catulo da Paixão Cearense (Guérios, 2003). Em contrapartida, certamente os intelectuais menores não ignoravam as concepções dos seus pares maiores. O entrecruzamento fortuito entre as elaborações das duas classes de intelectuais engendrou um espaço ímpar de produção de "verdades", onde os "grandes", que se punham a dissertar sobre o elemento popular, amiúde encontraram o norteamento e a percepção dos parâmetros que regiam o microcosmo sobre o qual tencionavam enquadrar. Ao passo que, os cronistas-jornalistas deparavam-se com instrumentos teóricos e uma interpretação histórica abrangente, que facultavam maiores universalidade e legitimidade aos seus "humildes" labores legislativos.

Resquícios do folclorismo de Mário de Andrade são notórios nas obras de Vagalume e Orestes Barbosa, por exemplo. Vagalume adaptou ao samba urbano a noção de que as "puras" e "autênticas" manifestações 
eram as postadas no alto dos morros, quer dizer, as funcionais à comunidade da qual faziam parte, pois supostamente intocadas pela "corrupta" civilização, enquanto Barbosa preferiu romantizar a inefabilidade que pairava pelos ares acima da cidade:

Filho legítimo dos morros, o samba, por mais que queiram não morrerá, não perderá o seu ritmo. Os sambestros, que são os fazedores de músicas de samba, rivais dos maestros... procuram desviá-lo mas, ainda há gente nos morros que exige, que pugna, que vela, que mantém e fará respeitar a "toada", do samba tão nosso, tão brasileiro (Guimarães, 1978, p. 30).

O samba nasce no morro. Na crista da terra enfeitada pelas árvores, e onde há a poesia daqueles casinholos - pedaços de tábuas retas, um teto de zinco orquestral nas noites de chuvas, uma bananeira, um gato, a luz saindo pelas frinchas e, lá dentro, um violão e um amor! No morro vive um lirismo exclusivo, uma filosofia estranha, como que olhando a claridade do urbanismo que, afinal, olha pra cima, atraído pelas melodias, e sobe, então, para buscá-las e trazê-las aos salões (Barbosa O., 1978, p. 31).

De outra parte, apenas em 1933, isto é, junto com o lançamento de Na Roda do Samba, e cinco anos após o seu Ensaio sobre a música brasileira - onde condenava o samba urbano como um todo -, Mário de Andrade avaliou o gênero com discernimento de insider; arriscou-se a dividir, em Música, Doce Música, o joio do trigo, ou seja, os sambas a que ele atribuía valor daqueles "popularescos":

[...] O verdadeiro samba que desce dos morros cariocas, como o verdadeiro maracatu que ainda se conserva entre certa "nações" do Recife, esses, mesmo quando não sejam propriamente lindíssimos, guardam sempre, a meu ver, um valor folclórico inquestionável. Mesmo quando não sejam tradicionais e apesar de serem urbanos. [...] Mas o que aparece nesses concursos [de carnaval], não é o samba do morro, não é coisa nativa muito menos instintiva. Trata-se exatamente de uma submúsica, carne para alimento de rádios e 
discos, elemento de namoro e interesse comercial, com que fábricas, empresas e cantores se sustentam, atucanando a sensualidade fácil de um público em via de transe. Se é certo que, vez por outra, mesmo nesta submúsica, ocasionalmente ou por conservação de maior pureza inesperada, aparecem coisas lindas ou tecnicamente notáveis, noventa por cento desta produção é chata, plagiária, falsa como as canções americanas de cinema, os tangos argentinos ou fadinhos portugas de importação. (Andrade, 1976, p. 280-281).

Sinal de que os "doutores em sambice", modo pelo qual, com um bocado de despeito, Mário denominou os entendidos em matéria que ele não dominava por completo no excerto seguinte, acabaram exercendo alguma ascendência sobre o mestre:

[...] E há os entendidos de marchinhas e principalmente de sambas, que, nutrindo um secreto desespero por não saberem profundamente música, sustentam no entanto a tese que, neste caso, misterioso de sambas e batucadas, ser músico não adianta para discernir o melhor. Deste gênero de doutores em sambice, possuo dois amigos que vivem me martirizando em minhas preferências. Ambos acham que, por mais sabedor de três quiálteras e quintas aumentadas que eu seja, me falta principalmente aquela necessária dose, não sei se de malandragem ou de carioquice, para dar qualquer opinião. Sempre faço, aliás, meus melhores esforços para me pôr na escola deles, mas o cômico da história é que nem eles mesmos se combinam, e um vive a maldar do outro, dizendo que o outro não entende da coisa, que ele é quem conviveu com Noel Rosa ou subiu o morro, em busca das mais perfeitas exatidões. (Andrade, 1976, p. 279).

\section{V - Costurando o samba}

Conforme visto, no instante em que determinados agentes, escorados em parâmetros referidos exclusivamente a um novo domínio artístico, deram a conhecer e formalizaram discursivamente e por atos a 
existência de uma manifestação musical popular "autêntica", contraposta a uma "inautêntica", outro plano de debate tomou a dianteira normativa. A legislação sobre as artes populares, formas até então despidas de especialistas vertidos sobre suas peculiaridades, tornar-se-ia mais nítida e efetiva. A lógica do embate que se dava anteriormente - aquele levado a cabo por personagens externas às manifestações em questão - permaneceu, com a ressalva de ter se plasmado em padrões de legitimidade caros à ordenação simbólica da nova arena cultural, a qual ganhava acabamentos formais e institucionais. Nela, o glamour distintivo passava a englobar tais ou quais formas populares mais "autênticas", não o elemento erudito tout court.

Tais indícios, de que uma realidade outra brotava da cisão decorrida do processo de autonomização do domínio social em questão, levaramme a lançar mão da tentativa de apreender os padrões resultantes do entrechoque envolvendo as duas dimensões de formulação legislativa. A posição social ocupada por cada um dos produtores de discursos foi empregada como matriz predominante no enquadramento daqueles que se postavam enquanto mais ou menos "internos" à manifestação artística que pretendiam discorrer sobre. Agrupei-os analiticamente em distintos planos valendo-me de conceitos já bem conhecidos na teoria linguística, os de ético e êmico ${ }^{7}$. O grupo retratado na terceira seção, quer dizer, formado por figuras aparentemente sem maiores interesses na emergente jurisdição do samba, da música popular e de sua dinâmica própria, mas atraídos, de outro lado, por questões "maiores" - tais quais as de or-

\footnotetext{
${ }_{7}^{7}$ Segundo o Dicionário Eletrônico Houaiss de Língua Portuguesa, ético adj. (d1954) linguística estrutural - na teoria tagmêmica, relativo à descrição e ao estudo das unidades linguísticas consideradas em termos físicos, sem correlação com sua função no sistema da língua. Por oposição a êmico etim ing. etic de (phon)etic 'fonético', 'relativo aos sons da linguagem em sua realização concreta'. êmico adj. (1954) linguística estrutural - na teoria tagmêmica, relativo à descrição e ao estudo de unidades linguísticas em termos da sua função dentro do sistema ao qual pertencem. Por oposição a ético etim ing. emic (1954) 'relativo aos fonemas e a seus traços distintivos', de phonemic 'fonêmico'.
} 
dem política, econômica, educacional, nacional etc. - com as quais estas formas artísticas, por sua vez, se imbricavam, fazem parte do plano dos discursos éticos. No geral, suas presenças na cena cultural eram notadas em razão de comentários externados sobre o que quer que fosse. Isto de maneira independente ao surgimento ou não de um domínio simbólico e institucional próprio à música popular urbana, haja vista suas existências sociais não se encontrarem atadas à emergência desse campo de produção artística: a autoridade de suas vozes era oriunda prioritariamente de capitais amealhados em esferas sociais diversas. Com o passar do tempo, de dominantes no vácuo outrora existente, passavam à condição de meros diletantes que tencionavam avalizar um universo simbólico dotado de gravitação própria, personagens que movimentavam polêmicas sobre o elemento musical popular esposando teses outras que não as intrinsecamente relacionadas ao objeto de que tratavam. Intelectuais e artistas maiores, políticos, altos burocratas do governo, literatos, folcloristas etc. completavam o rol daqueles que se pretendiam no direito de permanecer avaliando manifestações em locais distantes das instituições que agora Ihes davam contorno.

Já na dimensão dos formuladores de discursos que denomino de êmicos, atuavam aqueles que de fato deram concretude aos gêneros musicais populares urbanos, os que permitiram que seus limites encontrassem-se semiacabados e seus artistas e representantes "legítimos" parcialmente definidos no instante em que o primeiro ciclo de assentamento das instituições comerciais especializadas em dar vazão aos produtos musicais viu-se terminado. Neste plano, posicionavam-se as personagens menos conhecidas que demarcavam em páginas de jornal, folhetos carnavalescos, revistas de variedades, letras de canções e, ainda, em veículos inusitados, como as fofocas mantidas em cafés e na boêmia, as fronteiras do que poderia ser considerado samba ou não, de como esse estilo deveria 
ser reproduzido, dos sujeitos que, de fato, se ligavam às manifestações nascentes, dos locais originários que abrigavam seus fundadores, dos bons e maus compositores etc.

Jornalistas-foliões, boêmios-jornalistas, compositores-jornalistas, radialistas-cantores, cantores-jornalistas, compositores-radialistas, teatrólogos-jornalistas e todas as demais combinações cabíveis davam conta de suas atividades, todas elas de menor envergadura social e intelectual em comparação com as de seus pares éticos. Ao passo que construíam o princípio de sobrevivência, por meio da especialização no assunto música popular urbana, participavam, ainda, da produção artística dessas manifestações. Mais do que isso: seus interesses primários, ao contrário dos agentes do plano de discurso ético, restringiam-se aos gêneros emergentes nos quais tomavam parte. A efetividade de suas ações, no mais, solidificou-se tãosomente no instante em que as instituições que os acolhiam demonstravam certa madureza, a ponto de os sustentarem econômica e espiritualmente. $\mathrm{E}$ é aqui que os relatos e estórias dados a conhecer por meio dos veículos que os abrigavam puderam transfigurar-se nos futuros mitos voltados à santificação dos sambistas, prestando-se, assim, à delimitação simbólica do gênero samba. Seus produtos suscitaram os traços invariantes que conformam a legislação sobre o elemento musical popular urbano, preparando, por conseguinte, a ascensão dessas manifestações ao mundo das pautas legítimas, a chancela de suas existências junto a públicos diferenciados e o surgimento de divisões interiores. Só se discute sobre o que é discutível, e neste ponto era anunciada a chegada do samba.

Com respeito à inter-relação eventualmente estabelecida entre os portadores de discurso dos dois planos, foi observado, de acordo com variadas situações analisadas, que ela pode se evidenciar de muitas maneiras, embora um movimento de caráter geral costume vicejar; à medida que se dê a autonomização do domínio simbólico que enlaça os prota- 
gonistas em questão, irrompe certa distância mútua entre os dois grupos, haja vista que ambos, doravante, tendam a se ocupar essencialmente da elaboração de respostas àqueles situados em posições sociais parelhas às suas. Deve ser lembrado, novamente, que os emissores éticos apresentam maior prestígio social no campo do poder, pois quando se trata de asserções favoráveis sobre manifestações ou artistas populares, ou de análises teoricamente mais sofisticadas - como as entabuladas por folcloristas, por exemplo -, muitos dos veredictos terminavam absorvidos e reelaborados por alguns dos êmicos, isto é, por parcela dos mais atentos às produções intelectuais do universo legítimo. A retroalimentação entre os planos, no entanto, era passível de ocorrer, uma vez que, por diversas vezes, os éticos recorreram às citações dos êmicos a fim de alardear familiaridade com o universo popular quando lhes convinha - caso citado de Mário de Andrade, intelectual ético por excelência. Fazendo uso de informações parcialmente sistematizadas e amiúde ignoradas tanto pelos seus adversários quanto pelo público ao qual se dirigiam, terminavam por adquirir aura de entendidos no assunto.

Por outro lado, tornava-se latente a possibilidade de ser deflagrado um conflito direto envolvendo os pertencentes a dimensões diversas. A primeira forma dizia respeito ao instante em que algum êmico arrivista, que eventualmente tivesse conquistado prestígio em seu próprio domínio, buscasse o reconhecimento irrestrito em âmbitos mais alargados. Neste sentido, o intelectual êmico chocava-se com detentores de opiniões - por mais pertinentes e respeitados fossem seus emissores - que se aventurassem em sua exclusiva jurisdição. Aqui podemos listar o exemplo de Ari Barroso, reconhecido como exímio compositor popular e radialista que se aventurou a enfrentar no terreno discursivo ninguém menos do que Villa-Lobos (McCann, 2004, p. 73). O segundo caso seria o do "recado" ao desentendido que detratasse o elemento popular. Na verdade, mais 
uma chamada à ordem, reafirmando a autonomia e a autoridade de sua esfera de ação e de discurso, do que uma resposta em termos diretos - o que seria, em tese, tarefa dos pares éticos simpáticos à ascensão do popular. Os êmicos valiam-se, ainda, nesta mesma situação, de maneiras expressivas que não a mera escrita - como os versos de canções -, aproveitando assim para revelarem em suas réplicas destrezas entremeadas à própria matéria artística - caso da célebre canção "Pra quê discutir com a madame", de Haroldo Barbosa e Janet de Oliveira, que continha em seus versos humorísticos críticas ferinas dirigidas a uma articulista do rádio famosa por destratar o samba nos anos 1940 (Garcia, 2001). No mais das vezes, no entanto, o padrão foi contrário a estes dois exemplos. Os êmicos, intelectuais dominados em busca de reconhecimento, escoravam-se no prestígio dos éticos a fim de justificar suas atividades e o "valor" do empreendimento em que se especializavam. Citavam a mancheias nomes consagrados que referendassem suas assertivas, como os de Mário de Andrade, Manuel Bandeira, Carlos Drummond de Andrade, Vinícius de Moraes e outros maiorais reconhecedores da "riqueza" do universo do samba.

Óbvio que, com os exemplos listados, não esgoto as possibilidades de tipos de relacionamento que se davam entre os distintos planos de elaboradores de discursos. Importa ressaltar, no entanto, que contatos desse jaez suscitaram vida simbólica ao jogo de poder que enformou o domínio em pauta. Sem se ater a relações muitas vezes contraditórias e aparentemente desprovidas de um sentido maior, torna-se difícil vislumbrar a maneira pela qual se imbricam as autonomias discursiva e estruturo-musical, dado que personagens aparentemente marginais à atividade artística protagonizaram a fixação de limites precisos a algumas manifestações que, dentro de pouco tempo, vieram a ser consideradas "nacionais".

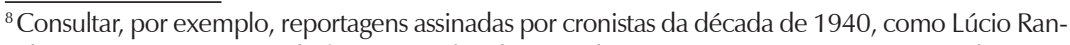
gel, ou ouvir programas radiofônicos produzidos por Almirante (Wasserman, 2002; Stroud, 2008). 
Cabe lembrar, ainda, que tal armação dual de planos de discursos erigidos em torno do elemento musical popular urbano, armação esta gestada nos primeiros trinta anos do século XX, sobreviveu ao longo do tempo, tornando-se verdadeiro invariante a constranger os possíveis da criação artística até nossos dias (Fernandes, 2010).

Por fim, embora seja difícil afirmar a priori a extensibilidade da proposição metodológica a objetos diversos, penso que outros domínios culturais dotados simultaneamente de relativa autonomia simbólica, institucional e legislativa, como ainda de parco prestígio no universo social, podem se prestar a investidas analíticas tais quais a ensaiada. Falo, aqui, de outras formas musicais populares, como ainda e hipoteticamente do futebol, da fotografia etc. Isto, pela razão de que o estatuto desses espaços funda-se justamente no interstício florescido entre a ordem social legítima e ilegítima, em seus mais variados espectros. No caso examinado, espero ter deixado claro que se tratava de atividade carente de atributos louváveis pela "boa" sociedade, em determinado período, que galgou posição de destaque ao longo do tempo, conformando, ao final e por meio de relações tecidas entre mundos intelectuais díspares, uma prática munida de gravitação simbólica própria. Muitas atividades outrora rebaixadas foram alçadas à glória de modo similar, consistindo em campos de disputas e construções intelectuais a serem mais bem delineados ao molde da análise operada.

\section{Referências}

1. ANDRADE, Mário de. Música, Doce Música. 2. ed. São Paulo: Livraria Martins Editora, 1976.

2. BARBOSA, Marialva. História Cultural da Imprensa - Brasil (1900-2000). Rio de Janeiro: Mauad, 2007.

3. BARBOSA, Orestes. Samba: sua história, seus poetas, seus músicos e seus cantores. 2. ed. Rio de Janeiro: Edição Funarte, 1978. 
4. BARBOZA, Marília; OLIVEIRA FILHO, Arthur. Filho de Ogum Bexiguento. Rio de Janeiro: FUNARTE, 1979.

5. BISSOLI, Magno. Caixa preta: samba e identidade nacional na era Vargas - impacto do samba na formação da identidade na sociedade industrial 1916-1945. 2004. Tese (Doutorado em História Social) - Programa de Pós-Gradação em História Social da Faculdade de Filosofia, Letras e Ciências Humanas, Universidade de São Paulo, São Paulo.

6. BOURDIEU, Pierre. A Produção da Crença. São Paulo: Zouk, 2004.

7. BRAGA, Luís Otávio. A invenção da música popular brasileira: de 1930 ao final do Estado Novo. 2002. Tese (Doutorado em História) - Programa de PósGraduação em História do Instituto de Filosofia e Ciências Sociais, Universidade Federal do Rio de Janeiro, Rio de Janeiro.

8. CABRAL, Sérgio. A MPB na Era do Rádio. São Paulo: Moderna, 1996a.

9. CABRAL, Sérgio. As Escolas de Samba do Rio de Janeiro. 2. ed. Rio de Janeiro: Lumiar, , 1996b

10. CALDEIRA, Jorge. Voz Macia: O Samba como Padrão de Música Popular Brasileira, 1917-1939. 1982. Dissertação (Mestrado em Sociologia) - Programa de Pós-Gradação em Sociologia da Faculdade de Filosofia, Letras e Ciências Humanas, Universidade de São Paulo, São Paulo.

11. CASÉ, Rafael. Programa Casé: O Rádio começou aqui. Rio de Janeiro: Mauad, 1995.

12. COUTINHO, Eduardo Granja. Os cronistas de momo: imprensa e carnaval na Primeira República. Rio de Janeiro: Ed. UFRJ, 2006.

13. CUNHA, Fabiana Lopes da. Da Marginalidade ao Estrelato - o samba na construção da nacionalidade (1917-1945). São Paulo: Annablume, 2004.

14. EFEGÊ, Jota. O Cabrocha: meu companheiro de farras. Rio de Janeiro: Casa Leuzinger, 1931.

15. FENERICK, José Adriano. Nem do Morro Nem da Cidade: As Transformações do Samba e a Indústria Cultural (1920-1945). 2002. Tese (Doutorado em História Social) - Programa de Pós-Gradação em História Social da Faculdade de Filosofia, Letras e Ciências Humanas, Universidade de São Paulo, São Paulo.

16. FERNANDES, Dmitri Cerboncini. A Inteligência da Música Popular: a "autenticidade" no samba e no choro. 2010. Tese (Doutorado em Sociologia) Programa de Pós-Graduação em Sociologia da Faculdade de Filosofia, Letras e Ciências Humanas da Universidade de São Paulo, São Paulo.

17. FERNANDES, Dmitri Cerboncini. "E fez-se o samba": condicionantes intelectuais da música popular no Brasil. Latin American Music Review, Austin, v. 32, n. 1, 2011. 
18. FRANCESCHI, Humberto Moraes. A Casa Edison e seu Tempo. Rio de Janeiro: Sarapuí, 2002.

19. FROTA, Wagner Nunes. Auxílio Luxuoso: Samba Símbolo Nacional, Geração Noel Rosa e Indústria Cultural. São Paulo: Annablume, 2003.

20. GARCIA, Tânia da Costa. Madame Existe. Revista FACOM: revista da Fundação Armando Álvares Penteado - FAAP, São Paulo, n. 9, 2. sem., 2001.

21. GUÉRIOS, Paulo Renato. Heitor Villa-Lobos: o caminho sinuoso da predestinação. Rio de Janeiro: FGV, 2003.

22. GUIMARÃES, Francisco "Vagalume". Na Roda do Samba. 2. ed. Rio de Janeiro: Funarte, 1978.

23. McCANN, Brian. Hello, Hello Brazil: Popular Music in the Making of Modern Brazil. Estados Unidos da América: Duke University Press, 2004.

24. MORAES, José Geraldo Vinci de. Os Primeiros Historiadores da Música Popular Urbana no Brasil. ArtCultura - Revista de História, Cultura e Arte do Instituto de História da Universidade Federal de Uberlândia, v. 8, n. 13, Uberlândia, 2006.

25. MOURA, Roberto. Tia Ciata e a pequena África no Rio de Janeiro. 2. ed. Rio de Janeiro: Prefeitura da Cidade do Rio de Janeiro, 1995.

26. NAPOLITANO, Marcos. A Música Popular Brasileira (MPB) dos anos 70: resistência política e consumo cultural. In: CONGRESSO DE LA RAMA LATINOAMERICANA DEL IASPM, 4., Cidade do México, 2002. Anais... Cidade do México: IASPM, 2002.

27. NAPOLITANO, Marcos. A Síncope das Idéias: a questão da tradição na música popular brasileira. São Paulo: Perseu Abramo, 2007.

28. NAPOLITANO, Marcos; WASSERMAN, Maria Clara. Desde que o samba é samba: a questão das origens no debate historiográfico sobre a música popular brasileira. Revista Brasileira de História, São Paulo, v. 20, n. 39, 2000.

29. NAVES, Santuza Cambraia et al. Levantamento e Comentário Crítico de Estudos Acadêmicos sobre Música Popular no Brasil. In: BIB: Revista Brasileira de Informação em Ciências Sociais, São Paulo, n. 51, p. 49-84, 2001.

30. PEDRO, Antonio. Samba da Legitimidade. 1980. Tese (Doutorado em História Social) - Programa de Pós-Gradação em História Social da Faculdade de Filosofia, Letras e Ciências Humanas, Universidade de São Paulo, São Paulo.

31. PINTO, Alexandre Gonçalves "Animal". O Choro. 2. ed. Rio de Janeiro: Funarte, 1978. 
32. RIVRON, Vassili. Le goût de ces choses bien à nous: la valorisation de la samba comme emblème national (Brésil, annés 1920-1940). Actes de la recherches en sciences sociales, Paris, n. 181-182, p. 181-182, mars 2010.

33. SANDRONI, Carlos. Feitiço Decente: Transformações do Samba no Rio de Janeiro (1917-1933). Rio de Janeiro: Jorge Zahar; Ed. UFRJ, 2001.

34. SHAW, Lisa. The social history of the Brazilian samba. Londres: Ashgate, 1999.

35. STROUD, Sean. The Defence of Tradition in Brazilian Popular Music. Londres: Ashgate, 2008.

36. TINHORÃO, José Ramos. História Social da Música Popular Brasileira. São Paulo: 34, 2004.

37. VASCONCELLOS, Gilberto; SUZUKI, Matinas. A Malandragem e a Formação da Música Popular Brasileira. In: Sérgio Buarque de Hollanda (org.). História Geral da Civilização Brasileira, São Paulo: Difel, 1985. (v. 3).

38. VIANNA, Hermano. O Mistério do Samba. Rio de Janeiro: Jorge Zahar, 1995. 39. WASSERMAN, Maria Clara. "Abre a cortina do passado": A Revista da Música Popular e o pensamento folclorista (Rio de Janeiro: 1954 - 1956). 2002. Dissertação (Mestrado). - Programa de Pós-Graduação em História da Universidade Federal do Paraná, Curitiba.

40. WISNIK, José Miguel; SQUEFF, Ênio. Música: O Nacional e o Popular na Cultura Brasileira. 2. ed. São Paulo: Brasiliense, 1983.

Recebido em: 01/12/2011

Aceite final: 26/01/2011 